\title{
Bio-composting oil palm waste for improvement of soil fertility
}

\begin{abstract}
Sources of bio-compost as agro-industrial wastes includes wide range of oil palm wastes viz. waste, biomass, palm kernels, empty fruit bunch, mill effluent, trunk and frond compost. Various composting processes are summarized in brief with distinct reference of oilï palm composting covering aerated static pile, and co-composting with earthworms (vermicomposting). However, in-vessel composting and windrow composting has meritorious advantages in composting. This review article refers to various significant roles played by microorganisms associated. Noteworthy study of bio-compost applications and procedures are correspondingly glosses framework of ecological, economical and agroecosystemic benefits.
\end{abstract}

Keyword: Agro-industrial waste; Composting process; Co-composting; Inorganic fertilizer; Organic fertilizer 